\title{
Bending Strength and Stiffness of a Particulate Composite Material Manufactured with Epoxy Matrix and Corymbia Citriodora Sawdust
}

\author{
Hélder Rafael Santos Pascoal ${ }^{1}$, Se rgio Luiz Moni Ribeiro Filho ${ }^{1}$, Ge raldo Robe rto de Sous a ${ }^{1}$, \\ Francisco Antonio Rocco Lahr², André Luís Christoforo ${ }^{1, *}$ \\ ${ }^{1}$ Department of Mechanical En gin eering, Federal University of São João del-Rei (UFSJ), São João del-Rei, 36307-352, Brazil \\ ${ }^{2}$ Department ofStructural Engineer ing, Schoolof Engineer in gof SãoCarlos (EESC/USP), São Carlos, 13566-590, Brazil
}

\begin{abstract}
This research had as objective the development of particulate composite materials in epoxy matrix reinforced with Corymbia citriodora sawdust. The evaluated properties were bending modulus of elasticity (MOE) and bendingstrength (MOR). The resin volu metric fraction over wood sawdust was the only variab le factor at experimental design, consisting $45 \%$ and $65 \%$ in fractions. The thickness of specimens for the bending test was $4 \mathrm{~mm}$, defined at preliminary studies. Were fabricated two panels by investigated fractions, with $200 \times 200 \mathrm{~mm}$ dimensions, under a press pressure of $3 \mathrm{MPa}$, and made at ambient temperature, in different times. From these panels, were extracted the specimens test with dimensions and specifications established by American Standard ASTM D790: 2010. From results obtained from analysis of variance, concluded that variation of sawdust fraction present a significant behavior at response-variables, presenting the best results the materials manufactured with $45 \%$ of epoxy resin.
\end{abstract}

Keywords Particu late Composite, Sawdust, Mechanical Characterization

\section{Introduction}

Due the necessity of materials with properties that satisfyan ever more demanding market, the utilization of composite materials is growing in last years. As examples, may be mentioned its use at automotive, aeronautic and civil construction. Composite materials are multiphasic materials that show superior properties them their individual phases, providing a synergic effect[1], and can be divided in two types: Re inforced with particles and reinforced with fibers. Among particulate reinforced composites, reinforced with natural fibers are focus at currently developed research, especially wood sawdust, due the growing concern about environment questions.

La Mantia[2] define these materials, which use natural resources, like green composites. The using of sawdust like reinforced assists to decrease the quantity of spoilage gener ated in sawmills and furniture producers [3, 4].

Assumpção et al.[5]studied the effect of sawdust addition in mechanical properties of polymeric matrix composites. Were investigated two factors: Partic le size (10/20 US-Tyler and 100/200 US-Tyler) and mass of sawdust fraction $(40 \%$,

* Corresponding author:

alchristo foro@y ahoo.com.br (André Luís Christoforo)

Published online at http://journal.sapub.org/cmaterials

Copyright (C) 2013 Scientific \& Academic Publishing. All Rights Reserved
$60 \%$ and $80 \%$ ), leading to six distinct experimental conditions. Were evaluated apparent density, bending modulus of elasticity and bending strength. For both develo ped tests, were manufactured five specimens and two replicates. The authors concluded that using $60 \%$ of sawdust with particle size of 100/200 US Ty ler presented substantial improvements in every mechanical properties, being observed decrease in the composites manufactured with particles size from mash 10/20 US-Tyler.

Hisham et a1.[6] investigated the effect caused in mechani cal properties: bending modulus of elasticity and bending strength modulus, in composites manufactured with epoxy resin and reinforced with particulate wood sawdust or wood chips. In this research, epoxy resin was used at $14 \%$ in weight of the sawdust. Test specimens were handmade, using open casting process. The bending test confirmed the good mechanical behavior from composites, having both showed similar results. Concluded that this kind of composite can be used as anoptionatfurnitureproduction.

Norashikin et al.[7]investigated the performance of biodegradable composite films of chitosan, starch and wood sawdust fibers. The main objectives were the manufacture and characterization of morphological and physical properties of this material. The specimens were prepared using casting method, using sawdust as reinforcement and starch as matrix. For morphological characterization, was used atomic force microscopy and concluded that composite 
has a regular structure. Thermal properties were measured using thermogravimetry and differential calorimetry, and revealed that composites presented a little difference between fusion and degradation temperatures.

Machadoet al.[8] studied mechanical, thermal and rheological properties of Poli-3-hydroxybutyrate (PBH), consisting in a biodegradable thermoplastic, and $\mathrm{PBH}$ used as polymeric matrix with sawdust reinforcement. The specimens were manufactured via casting injection process. Concluded that incorporation of sawdust increased the crystalinity degree, crystallization temperature and hardness of composites. The best proportion found of $\mathrm{PBH} / \mathrm{Sawdust}$ among studied (90/10, 80/20,70/30) was 70/30.

Vitoriano and Felipe[9] studied the influence of wood sawdust in mechanical properties of polymeric matrix composites. Were used Jatobá Hymenaea SP wood sawdust, fro $m$ sawmills. Was performed a granulo metric characterizat ion of particles. Sawdust was used as load in orthophthalic polymeric matrix, accelerated and homogenized, then added to sawdust, and composite was leaked into a rectangular mold. Were manufactured four panels with different mass fractions. After cured, to density test, were extracted five specimens from each panel, totaling 20 samples and, for bending test, were used 7 specimens, totalizing 28 samples to determinate bending strength, bending modulus of elasticity and apparent density, in order to verify the influence of sawdust levels in these properties. Concluded that the increase of mass level of sawdust resulted in reduced density and mechanical properties evaluated.

Redigh ieri and Costa[10]p roposed utilization of reforesta tion wood sawdust (Eucalyptus) instead Pinus wood, traditionally used, andlow density polyethylene as matrix (LDPE) to manufactured composites. The LDPE, functionali zed with maleic anhydride (PE-g-MA)was used at sawdust treatment to improve adhesion between matrix and disperse phase. Were fabricated test specimens, using sawdust treated with PE-g-MA and without treatment. Then were performed bending and water absorption tests, concluding that PE-gMA worked as compatibilizing agent, improving adhesion between matrix and sawdust particles, optimizing its mechanical properties and decreasing water absorption.

Pedieu e Ried 1[11] evaluated the use of outer bark of white birch in external surfaces of a 3-layers composite panel,due its hydrophobic characteristics to decrease water absorption. External layers were made with these particles, vary ing its fraction in three levels and, at internal layer, were used coarse wood particles orfibers. Were manufactured four panels for each evaluated condition, amounting 24 panels. Panels with wood particles in its core showed improvements in mechanical and physical properties, satisfying internal use requirements for particulate panels. The best condition was obtained from panel with $45 \%$ of outer bark particles and $55 \%$ of wood particles in core, due the best dimensional stability.

According Jaeger and Ziger[12], due shortage of traditional raw materials like Pinus, has been occurring a growing Eucalyptus consumption. Therefore, at some places it's already used a mixture of Eucalyptus with another wood species to increase raw material. In this research, was proposed to compare compensated PinusTaeda panels (1) and Pinus Taeda mixed with Eucalyptus Dunnii(2) performance. Each panel was composed by nine sheets, only of Pinus Taeda, in case (1), and intercalated sheets of Pinus Taedaand Eucalyptus Dunnii in case (2). In this last, the central sheet was an E. Dunni sheet. Were performed bending tests at parallel and perpendicular directions and shear tests in glue lines.At shear tests, were used dry test specimens and also after two pretreatments, in hot water and in cold water to verify the possibility of use in external areas. In cold water treatment, was lost $16 \%$ of (1) specimens because they unbonded. In hot water treatment, $26 \%$ of (1) specimens and $23 \%$ of (2) were discarded.With this research, the authors concluded that mixture of Eucalyptus Dunnii with Pinus Taeda decrease the performance of the materials produced, and the panel which was used just Pinus Taeda showed higher bending modulus of elasticity and bending strength in both cut directions, however, the wood mixture presented lower problems about panels swelling afterhaving been immersed in water.

Naja fiet a1.[13] studied water absorption in plastic-wood composites, made with sawdust and polymers (Polyethylene and Polypropylene) rawor recycled.Th is components were mixed in weight fraction of $50 \%$. The panels were fabricated using compressing casting, with $2 \mathrm{~mm}$ thickness and $15 \mathrm{~cm} \mathrm{x}$ $15 \mathrm{~cm}$ casts using a hydraulic hot press at $170^{\circ}$ and $190^{\circ}$ for polyethylene and polypropylene respectively. The water absorption was evaluated keeping the composite under water for several weeks.Were concluded that maximum water absorption is bigger for composite manufactured with recycled polymers, and saturation time decreases when it's used.

Viannaet al.[14] verify that thin wood particles can be efficiently used to substitute minerals charges and glass fibers, showing mechanical properties appropriate to engineering applications. However, the interfase between matrix and fiber consist in a problem to solve in the manufacture of th is kind of material.

According Correa and Fonseca[15],wood composite preparationisnot a recentpractice. Since the 70 's, automobili stic industry uses wood sawdust as charges in thermoplastic, using this composite of polypropylene with wood particles to

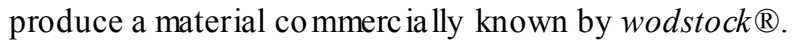

Maldas and Kokta[16] observed the recyclable behavior of composites made with wood sawdust and polystyrene, measuring its mechanical properties and its dimensional stability under normal conditions (room temperature) and under extreme conditions, exposure to room temperature, water and boiling water, and in temperatures above $150^{\circ} \mathrm{C}$ and below $-20^{\circ} \mathrm{C}$. Results from untreated composites and after the several treatments were compared. The recycled composites did not change significantly. Under all extreme conditions, thermoplastic composites presented superior mechanical properties and dimensional stability, even after recycling. 
Due the good properties presented at previous studies and possibility of reutilize wood sawdust, whichis incorrectly discarded, this researchaimed to the evaluate thebending modulus of elasticity (MOE) and bending Strength (MOR), of particulate composite materials with epoxy matrix reinforced Corymbia Citriodora sawdust,allowing evaluate the influence of the volumetric fraction of resin $(45 \%$ and $65 \%$ ) in the mechanicalproperties.

\section{Material and Methods}

The composite were manufactured and tested at the Materials Laboratory of theDepartment of Mechanical Engineering of the Federal University of São João del-Rei, Brazil. The evaluated factor was volumetric fraction of resin over sawdust $(45 \%$ and $65 \%)$ in mechanical properties: bending modulus of elasticity and bending strength modulus. To investigate the influence of resin fraction used on the response-variables, was used an analys is of variance (ANOVA), performed with aid of MiniTabsoftware, version 14.

The panelsproduced according the following steps: sawdust preparing, calculation of the quantityof sawdust and resin necessary, preparation of res in-sawdust mixture, panels fabrication, specimens cutting and preparation for tests. Samples ready, were performed bending tests. The sawdust used as reinforcement in composite was from Corymbia Citriodorawood specie.Sawdust was sieved in the size range 50-80 US-Tyler (Figure 1), had its moisture content controlled to $12 \%$, accord ing to Brazilian standard ABNT NBR 7190[17], and went through a pycnometry test to determine its density, that was $1,57 \mathrm{~g} / \mathrm{cm}^{3}$.

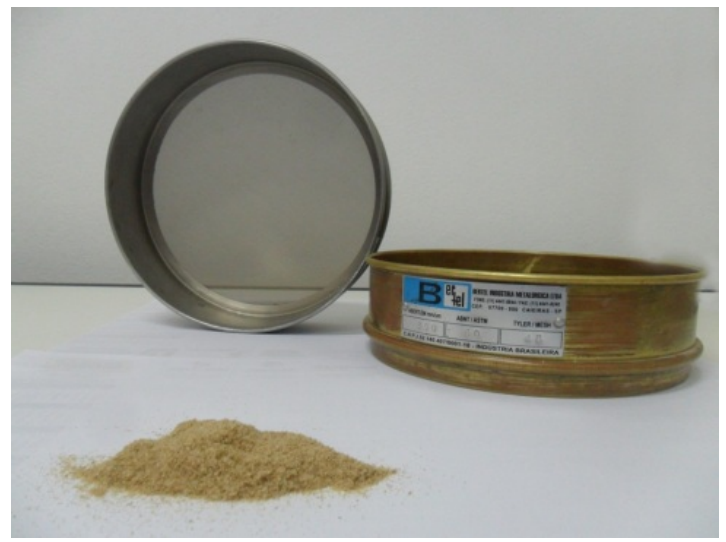

Figure 1. Sieves and sawdust

For matrix was used epoxy resin and hardener from Resiqualy ${ }^{\circledR}$, co mpany located at São Paulo city (Brazil-SP). According to manufacturer information, resin density is nearly $1,13 \mathrm{~g} / \mathrm{cm}^{3}$.

\subsection{Prepar ati on of Resin-s awdust Mixture}

According to preliminary studies performed, was determined that the best resin volume proportion, seeking to use the least amount of it, was between $45 \%$ e $65 \%$, because in smaller proportions the composites presented weak adhesion between phases.

Initially, was necessary to define the mass of resin and sawdust for each fraction. From total, resin mass was used $20 \%$ of hardener, as specified by manufacturer. After this, resin and hardener were mixed for about 5 minutes and then sawdust was added. Sawdust and resin were mixed until it was reached a homogeneous appearance(Figure 2).

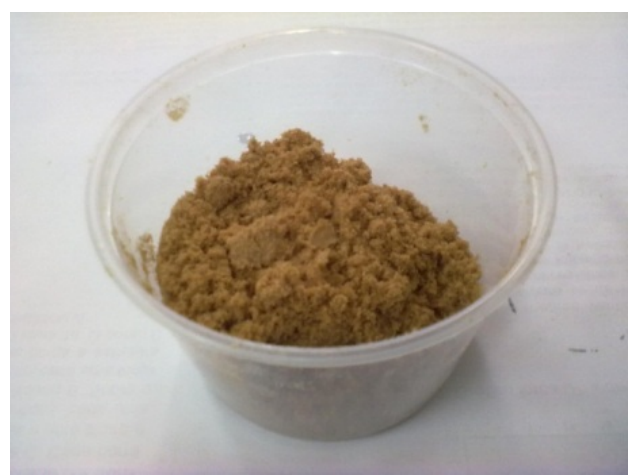

Figure 2. Mixture of epoxy resin and sawdust

\subsection{Panels Fabrication}

The panels fabricated were built with wood cast, covered with a mold release tissue (Armalon), with dimensions $200 \times 200 \mathrm{~mm}$. This mold is detachable, being its edges fastened with screws that must be released to remove the plate after curing period.

The mixture of resin and sawdust was placed in the mold (Figure 3 ), covering all its area with equals quantity.

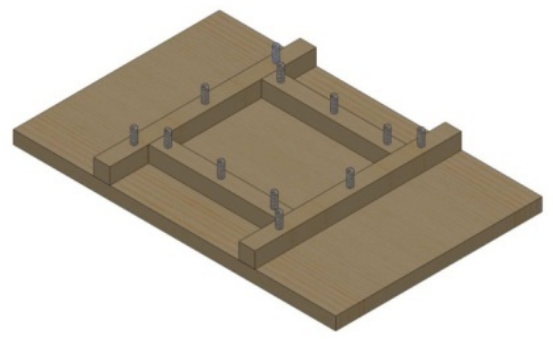

Figure 3. Mold

For uniform pressing of material, was used a metallic plate (covered with Armalon). Mold was prepared and led to a hydraulic press, using a press pressure of $3 \mathrm{MPa}$ for 24hours at ambient temperature.

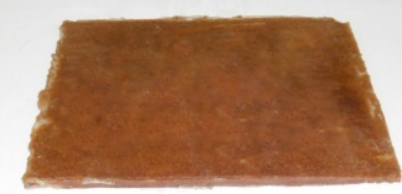

Figure 4. Panelextracted from the mold

After this, mold was taken out from press and 
dismounted to extract the panel. Figure 4 shows one of manufactured panels.

\subsection{Bending Tests}

After the panels manufacture, specimens were prepared for bending test (Figure 5) toevaluate the MOE and MOR, cut using an electric saw, and dimensions and standardizations of test preconized by American standard ASTM D790[18]. After cut, was necessary rigging the specimens to achieve exact dimensions. At the end of this process, dimensions of specimens to tests were 76,8 $\mathrm{mm} \times 12,7 \mathrm{~mm} \times 4 \mathrm{~mm}$. Of each manufactured panel, were extracted 28 specimens, amounting 56 specimens for experimental condition.

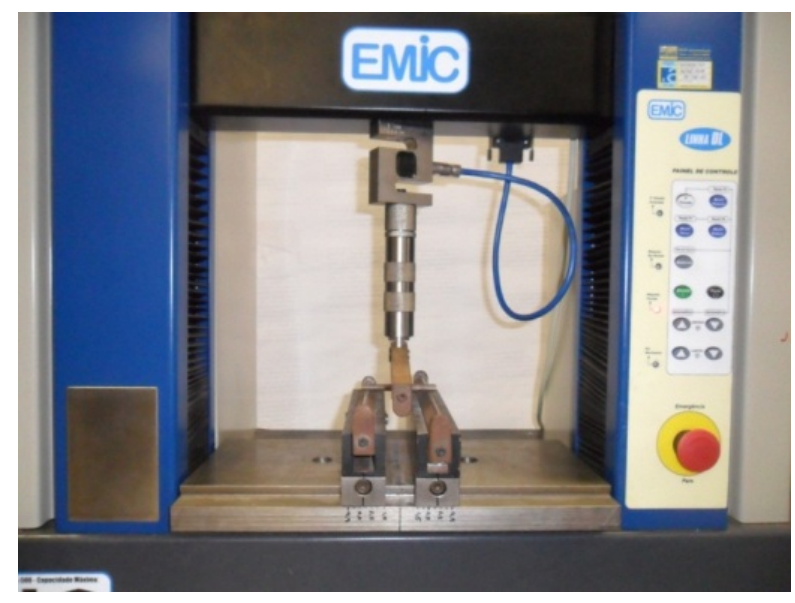

Figure 5. Bending test

\subsection{Scanning Electron Microscopy (S EM)}

After bending tests, a specimen of each condition was collected to be made a scanning electron microscopy, to verify particles homogeneity distribution at matrix phase. The photos were made using an electronic mic roscope from Hitachi brand, model TM3000.

\section{Results and Conclusions}

Table 1. Valuesofthe response-variablesevaluated

\begin{tabular}{ccc}
\hline Experimental condition & MOE (MPa) & MOR (MPa) \\
\hline CE1 (45\%) & $1578 \pm 18$ & $37,87 \pm 4,6$ \\
CE2 (65\%) & $815 \pm 13$ & $20,10 \pm 3,1$ \\
\hline
\end{tabular}

The mediumvaluesand standard deviationsobtained for each response-variable per experimental conditionevaluated are presented in Table 1.

Table 2 presents $\mathrm{P}$-Values and $\mathrm{R}^{2}$ coefficient for the response-variablese valuated. According Werkema and Aguiar[19], P-values smaller or equals $0,05 \quad(95 \%$ of confidence) are significant.

The Anderson-Darling normality testwas utilized to analyze residuals distribution obtained from ANOVA for each response-variableevaluated, being found P-values 0,71 and 0,36 for MOE and MOR, respectively, validating the use of the analysis of variance model.

Table 2. P-Valuesfrom the response-variables evaluated

\begin{tabular}{ccc}
\hline \multirow{2}{*}{ Experimental factor } & \multicolumn{2}{c}{ P-Values } \\
\cline { 2 - 3 } & MOE & MOR \\
\hline Resinfraction & 0,003 & 0,007 \\
$\mathrm{R}^{2}$ (Adj) [\%] & 89,15 & 83,01 \\
\hline
\end{tabular}

Figure 6 and 7 show the main effects plots for the resin fraction on MOE and MOR, respectively.

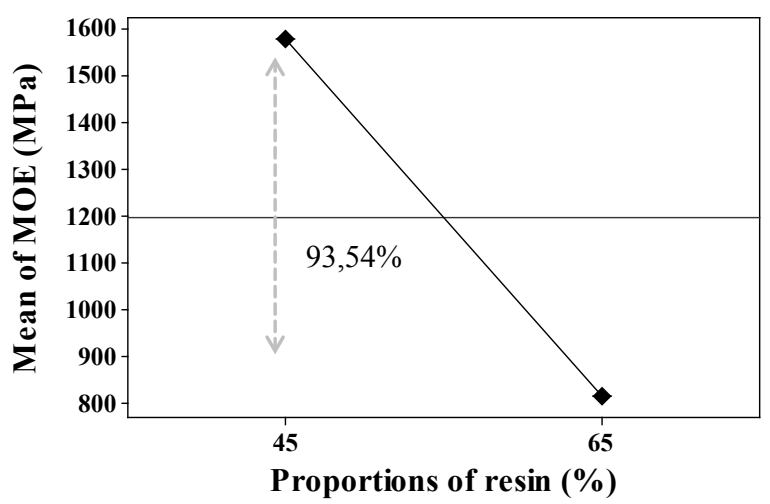

Figure 6. Main effect plotsforthe MOE

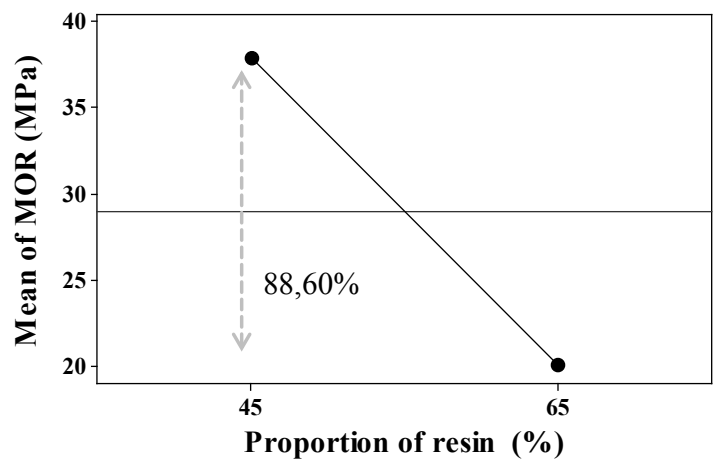

Figure 7. Main effect plotsfor theMOR

As presented on Table 2, the variation of resin fraction was significant in both response-variables evaluated. Comparing the results, it can be noted that in composites that used $45 \%$ of resin, the values of the bending modulus of elasticity and bending strength modulus were $93,54 \%$ and $88,60 \%$ respectively bigger than composites manufactured with $65 \%$ of resin content, as shown in Figure 6 and 7 .

Figure 8 and 9 show images obtained using SEM, from samples of composites with $45 \%$ and $65 \%$ of resin content, respectively, where can be noted the homogeneous distribution of particles, in both cases.

After analyze the results, was possible to conclude that volumetric resin fraction presented significant variations in the bending modulus of elasticity and in the bending strength modulus. The best results were obtained using $45 \%$ of resin content. In this way, it can be concluded that sawdust works as a good reinforce for epoxy resin, since that be respected a minimum limit, approximately $35 \%$ of resin content, 
because, in this proportion, the adhesion between matrix and particles decreaseand can easethe mechanical properties of the composite materials.

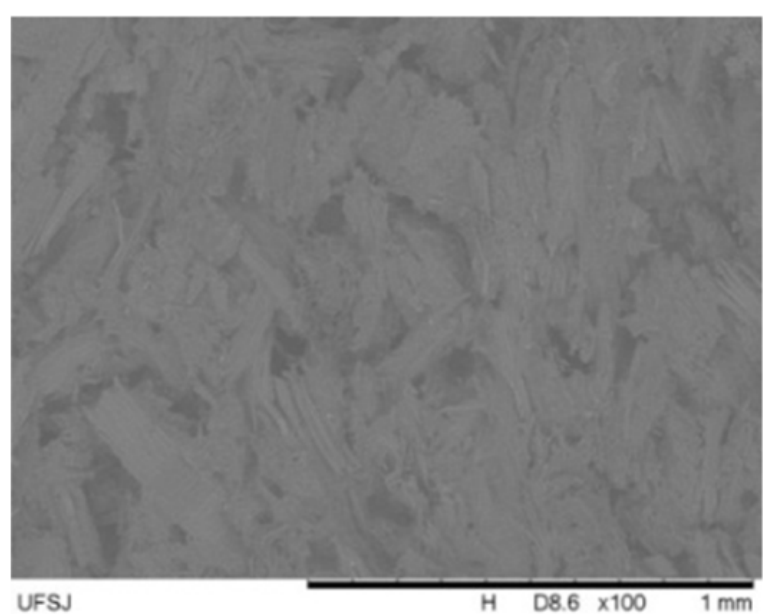

Figure 8. $45 \%$ of resin content - Zoom 100X

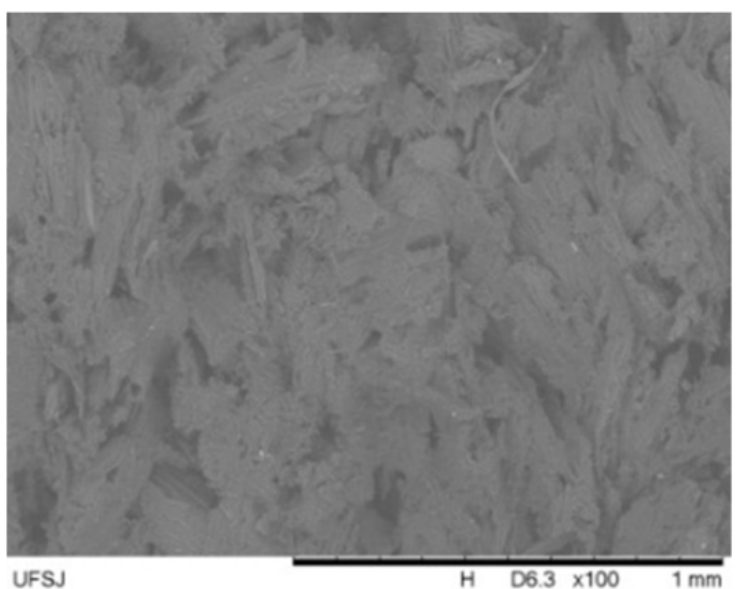

Figure 9. $65 \%$ of resin content - Zoom $100 \mathrm{X}$

\section{REFERENCES}

[1] W. D. Callister, “Ciência e Engenharia de Materiais: Uma Introdução", $7^{\text {a }}$ ed. LTC - Livros Técnicos e Científicos Editora S.A. Rio de Jan eiro, RJ. 2007.

[2] F. P. La Mantia, M. Morreale,"Green Composites: A brief review. Composites Part A: Applied Science and Manufacturing", v. 42, n. 6, p. 579 - 588. 2011.

[3] B. I. Kupcinov, V. G. Barsukov, V. M. Sapovalov, V. G. Rodnenkov, "Nove Kompozitni Materialyz Drevenych Trisek a Pilin - New Wood Chip and Sawdust Composite Materials", Plasty a kaucuk, v. 25, n.5, p. $136-138.1988$.

[4] M. Bengtsson, P. K. Oksman, "The Effect of Crosslink on the Properties of Polyethylene/Wood Flour Composites", Composites Science and Technology, v. 65, p. $1468-1479$. 2005.

[5] M. E. Assumpção, T. H. Panzera, A. L. Christoforo,"Estudo da Adição de Serragem em Compósitos Poliméricos", Revista Madeira: Arquitetura e Engenharia, v. 12, n. 28, p. 27 - 35.
2011.

[6] S. Hisham, A. A. Faieza, N. Ismail, S. M. Sapuan,M. S. Ibrahim,"Flexural Mechanical Characteristic of Sawdust and Chipwood Filled Epoxy Composites", 8th International Conference on Composite Science and Technology, ICCST8, Kuala Lumpur, Malasya. 2011.

[7] M. Z. Norashikin, M. Z. Ibrahim,"Fabrication and Characterization of Sawdust Composite Biodegradable film", World Academy of Science, Engineering and Technology, v. 65, p. $864-868$, United States. 2010.

[8] M. L. C. Machado, N. C. Pereira,L. F. Miranda, M. C. de Terence,"Estudo das Propriedades Mecânicas e Térmicas do Polímero Poli-3-Hidroxibutirato (PHB) e de Compósitos PHB/Pó de Madeira", Polímeros: Ciência e Tecnologia, v. 20, n. 1, p. $65-71.2010$.

[9] J. O. Vitoriano, R. C. Felipe, "Avaliação das Propriedades Mecânicas da Matriz Polimérica com Adição de Pó de Madeira", Anais do $10^{\circ}$ Congresso Brasileiro de Polímeros. Foz do Iguaçu, PR. 2009.

[10] K. I. Redighieri, D. A. Costa, "Compósitos de Polietileno Reciclado e Partículas de Madeira de Reflorestamento Tratadas com Polietileno Modificado", Polímeros: Ciência e Tecnologia, v. 18, n. 1, p. $5-11.2008$.

[11] R. Pedieu, B. Riedl, A. Pichette, "Phisical and Mechanical Properties of Panel Based on Outer Bark Particles of White Birch: Mixed Panels with Wood Particles Versus Wood Fibres", Maderas - Ciencia y Tecnología, v.10, n.3, p. 195 206. 2008.

[12] P. Jaeger, M. Ziger, "Avaliação das Propriedades Mecânicas de Painéis Compensados de Eucalyptus Dunnii e Eucalyptus Dunnii/Pinus Taeda", Cerne, Lavras, v. 13, n. 3, p. 329-338. 2007.

[13] S. K. Najafi, A. Kiaefar, E. Hamidina, "Water Absorption of Composites from Sawdust and Recycled Plastics", Journal of Reinforced Plastics and Composites, v. 26, n. 3, p. 341 - 348. 2007.

[14] W. L. Vianna, C. A. Correa, C. A. Razzino,“ Efeitos do Tipo de Poliestireno de Alto Impacto nas Propriedades de Compósitos Termoplásticos com Farinha de Resíduo de Madeira”, Polímeros: Ciência e Tecnologia, v.14, n. 5, p. 339 $-348.2004$.

[15] C. A. Correa, C. N. P. Fonseca, S. Neves, "Compósitos Termoplástico com Madeira", PPGECM, UAACET, Universidade São Francisco, 2003.

[16] D. Maldas, B. V. Kokta, "Effect of Recycling on the Mechanical Properties of Wood Fiber-Polystyrene Composites. II. Sawdust as a Reinforcing Filler", Polymer Plastics Technology and Engineering, v. 29, n.5-6, p. $419-$ 454. 1990.

[17] Associação Brasileira de Normas Técnicas. NBR7190 Projeto de estruturas de madeira. Rio de Janeiro, ABNT, 1997.

[18] ASTM Standard D790, 2010, Standard Test Method for Flexural Properties of Unreinforced and Reinforced Plastics and Electrical Insulating Materials. West Conshohocken, Pennsylvania. 2010.

[19] M. C. C. Werkema,S. Aguiar, "Planejamento e Análise de 
Experimentos: Como Identificar e Avaliar as Principais Variáveis Influentes em um Processo", Belo Horizonte:
Fundação Christiano Ottoni, Escola de En genharia da UFMG. 1996. 